\title{
FEATURES OF FREQUENCY ANALYSIS OF TORQUE CONTROL LOOP IN AC ELECTRIC DRIVES
}

\author{
A.N. Shishkov, shan1982@mail.ru, \\ D.A. Sychev, dmitry.epa@gmail.com, \\ N.V. Savosteenko,nikita.epa@gmail.com, \\ M.N.Krupnova, masha.krupnova.epa@gmail.com, \\ A.A. Zemlyansky, andrey.zemlyansky@gmail.com \\ South Ural State University, Chelyabinsk, Russian Federation
}

In the article, the structural scheme of the synchronous motor torque control channel is shown and mathematically described. Passing of a sine signal in the torque control loop is considered, equations for describing the dynamic properties of the current control loop are given. Specific features relating to the frequency characteristics of the channel for controlling of the electromagnetic torque in the adjustable variable speed drive with synchronous electric machines are considered. The control channel is regarded as a linear system with amplitude modulation. A comparative analysis of the experimental and calculated Bode plots of the current and torque control loops is carried out.

Keywords: electric drive, frequency control, bode plots, synchronous reluctance motor.

\section{Introduction}

$A C$ variable speed drives are operated by close loop scheme with the inner loop of the indirect control of the electromagnetic torque and outer loop - speed. In addition, in case there is a direct dependence between the armature current of the motor and its torque in typical $D C$ drive, that simplifies the inner loop setup, in $A C$ electric drives there is no such explicit dependence. The oscillate features of the description of dynamic properties of the electromagnetic torque actuating path in the variable-frequency electric drive with the synchronous and synchronous reluctance machine lower with use of the device.

\section{Theoretical}

The control loop of the torque (CLT) in the variable-frequency synchronous electric drive should be carried to multivariate the same systems of regulation with the amplitude modulation of the $U_{\text {in }}$ input signal. The sequence of mathematical operations, by means of which signal transmission processes through links of one phase of the synchronous motor stator are described, is illustrated by the block scheme. Here links are connected sequentially: $P C G B$ - phase current generated block; $C L C$ - the control loop of the stator phase current; $S M$ - the synchronous motor [1].

In a mathematical model of $P C G B$ after the operation of multiplication (modulating action) of the $U_{i n}$ input signal on a sine function is the $U_{\text {ref }}$ reference signal on the motor input $C L C$ :

$$
U_{\text {ref }}=U_{\text {in }} \sin \omega_{1} t,
$$

where $\omega_{1}$ - angular frequency of a modulating signal equal to the voltage set frequency to the frequency converter by the angular position sensor of the motor rotor; $t$ - time.

The modulating signal can be generated by the angular position sensor of the motor rotor directly that is seen in diagrams of the torque vector control formation [2] or via coordinate conversions of variables [3]. In the first case the spatial resultant vector of current of the stator is created in polar coordinates, in the second - in orthogonal. Then the signal $U_{\text {ref }}$ will be transformed by a control loop of the stator phase current $(C L C)$ to the stator current $I$ [4]. Connection between these values can be described by the $C L C$ transfer function:

$$
W_{C L C}(p)=i(p) / U_{\text {ref }}(p) \text {. }
$$

The link $S M$ considers interaction of the stator phase current $i$ with the excitation rotor. The electromagnetic torque of the motor $M_{i}$ resulting from this interaction is considered as an outcome of the current (i) secondary multiplication (demodulation) by the sinusoidal value of the same frequency, as to $P C G B$, but with the $\gamma-$ degree phase shift:

$$
M_{i}=L_{m} I_{r} i \sin \left(\omega_{1} t+\gamma\right),
$$

where $L_{m}$ - the maximum value of the mutual induction coefficient between the rotor winding and one of the stator phases; $I_{r}$ - rotor current of the synchronous motor; $\gamma$ - the angle of shift between the sinusoidal quantity given on inputs of $P C G$ Band $S M$ [5].

\section{Practical}

For application to the analysis of processes in the variable-frequency $A C$ electric drive of the standard device of the Bode plot and transfer functions will consider passing of a sine signal through links of one phase of the control loop of the torque [6].

Let give to the control loop input of the torque $C L T$ a sine signal of the frequency $\omega$, i.e.

$U_{\text {in }}=U_{m} \sin \omega_{1} t$,

Then to the output of the first unit of multiplication (a link $P C G B$ )

$$
\begin{aligned}
& U_{r e f}=U_{m} \sin \omega t \sin \omega_{1} t= \\
& =0,5 U_{m}\left[\cos \left(\omega-\omega_{1}\right) t-\cos \left(\omega+\omega_{1}\right) t\right] .
\end{aligned}
$$


We see that the first harmonic of frequency $\omega$ is lost, but two summary harmonicas appear $\left(\omega+\omega_{1}\right)$ together with the difference $\left(\omega-\omega_{1}\right)$ frequencies.

If dynamic properties of the CLC link are to describe amplitude $A_{C L C}(\omega)$ and the phase $\varphi_{C L C}(\omega)$ Bode plot, then a signal at its output can also be provided by the amount of two summary harmonicas and the difference frequencies:

$$
\begin{aligned}
& i=0,5_{m} A_{C L C 1}\left(\omega-\omega_{1}\right) \cos \left[\left(\omega-\omega_{1}\right) t-\phi_{1}\left(\omega-\omega_{1}\right)\right]- \\
& -0,5 U_{m} A_{C L C 2}\left(\omega+\omega_{1}\right) \cos \left[\left(\omega+\omega_{1}\right) t-\phi_{2}\left(\omega+\omega_{1}\right)\right] . \\
& \text { Here } A_{C L C 1}\left(\omega-\omega_{1}\right) \text { and } A_{C L C 2}\left(\omega+\omega_{1}\right)-\text { values }
\end{aligned}
$$
of the Bode plot of the gain of the $C L C$ link with frequencies $\left(\omega-\omega_{1}\right)$ and $\left(\omega+\omega_{1}\right) ; \phi_{1}\left(\omega-\omega_{1}\right)$ and $\phi_{2}\left(\omega+\omega_{1}\right)$ - the values of the phase-shift-frequency of the $C L C$ link with the same frequencies. Generally, these harmonicas differ among themselves on the amplitudes and the phase angle only in case when CLC is inertia less, the amplitudes and phases at them identical. After secondary multiplication in the $S M$ link each of harmonicas will again break up into two items, then

$M_{i}=L_{m} I_{r} i \sin \left(\omega_{1} t+\gamma\right)=0,25 U_{m} L_{m} I_{r} A_{C L C 1}\left(\omega-\omega_{1}\right) \times$

$\times\left\{\sin \left[\omega t+\gamma-\phi_{1}\left(\omega-\omega_{1}\right)\right]-\sin \left[\omega t-2 \omega_{1} t-\gamma-\phi_{1}\left(\omega-\omega_{1}\right)\right]\right\}+$ $+0,25 U_{m} L_{m} I_{r} A_{C L C 2}\left(\omega+\omega_{1}\right)-\left\{\sin \left[\omega t-\gamma-\phi_{2}\left(\omega+\omega_{1}\right)\right]-\right.$ $\left.-\sin \left[\omega t+2 \omega_{1} t+\gamma-\phi_{2}\left(\omega+\omega_{1}\right)\right]\right\}$.

It follows from the last expression that at output of the single-phase torque control loop the monosine signal $U_{i n}$ of the frequency $\omega$ will be transformed to the signal containing four harmonicas: two with the basic frequency $\omega$, but with different phase angles, and two harmonicas with the side frequencies $\left(\omega-2 \omega_{1}\right)$ and $\left(\omega+2 \omega_{1}\right)$. In the three-phase variablefrequency electric drive the electromagnetic torque of the synchronous motor is provided as a result of the combined action of three identical single-phase control loops connected in parallel. These control loops correspond to phases A, B and C of the stator and have the general input signal and the adder on the output [7]. Feature of this structure is that signals are multiplied in the links of $P C G B$ and $S M$ by the sinusoidal values forming a three-phase symmetric system among themselves. It leads to the fact that at the system output adder (which shall contain twelve items) two or three of sine curves are mutually equilibrated. In expression for the electromagnetic torque there are two trebled harmonicas of the basic frequency $\omega$. The amplitudes of these harmonicas and the value of their phase shifts are defined by the frequency responses of the CLC link of CLC on the side frequencies $\left(\omega-\omega_{1}\right)$ and $\left(\omega+\omega_{1}\right)$ :

$M=M_{A}+M_{B}+M_{C}=M_{1}\left(\omega-\omega_{1}\right)+M_{2}\left(\omega+\omega_{1}\right)=$ $=0,75 U_{m} L_{m} I_{r} A_{C L C 1}\left(\omega-\omega_{1}\right) \sin \left[\omega t+\gamma-\phi_{1}\left(\omega-\omega_{1}\right)\right]+$ $+0,75 U_{m} L_{m} I_{r} A_{C L C 2}\left(\omega+\omega_{1}\right) \sin \left[\omega t-\gamma-\phi_{2}\left(\omega+\omega_{1}\right)\right]$.

Let's consider the expression given above for the electromagnetic torque of the synchronous motor in more detail. In the elementary case we read $C L C$ as an inertialess link. In electric drives with a supply of windings of the stator from the gated transformers working in the current source mode, the bandwidth range of frequencies of $C L C$ reaches several thousand radianper second, so, the accepted assumption not only simplifies a pattern of processes, but also slightly distinguishes it from the true one. In case of the inertialess $C L C$ its Bode plot $\left(A_{C L C}=\right.$ const $)$ and the phase frequency characteristics $\left(\varphi_{C L C}=0\right)$ [8]. The vector of the resultant torque $(M)$ turns out as the amount of vectors, equal on length $\left(M_{1}\right.$ and $\left.M_{2}\right)$. At the same time, the vector $\left(M_{1}\right)$ advances the vector $\left(U_{i n}\right)$ by the angle $(\gamma)$, and the vector $\left(M_{2}\right)$ shifts behind on the same angle. The expression for the torque takes a form:

$$
M=1,5 U_{i n} L_{m} I_{r} A_{C L C} \cos \gamma,
$$

i.e., with a constant amplitude of the sine input signal of $U_{\text {in }}=$ const, we have $M=$ const overall the frequency band. If $\gamma=0$, then the directions of a vector of $U_{\text {in }}$ and composed by $M_{1}$ and $M_{2}$ match [9].

The frequency characteristics of the torque control loop, in case of the different fixed values $\omega_{1}$. Let's simultaneously compare the values $\omega_{1}$ and $\omega_{c}$. For descriptive reasons, we will provide items $\left(M_{1}\right.$ and $M_{2}$ ) in the vectorial form. Let us remind that these are sinusoidal values of the frequency $\omega$, amplitudes which phase shifts depend on the values of side frequencies $\left(\omega-\omega_{1}\right)$ and $\left(\omega+\omega_{1}\right)$. Let us address the CLT vectorial charts (Fig. 1) when $U_{\text {in }}$ vector is accepted to the basic (input) vector, and for a day off - the vector $(M)$ represented as the amount of items $\left(M_{1}\right.$ and $\left.M_{2}\right)$ [10].

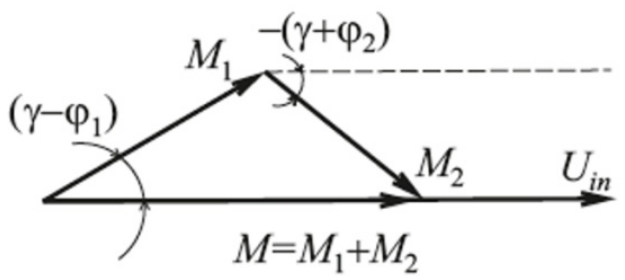

a)

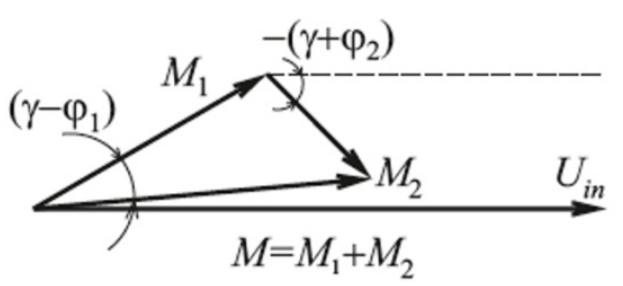

b)

Fig. 1. Sum of the torque component in the synchronous electric drive

At first, we will consider a case when $\left(\omega_{1}<<\omega_{c}\right)$ that is traced by operation of the electric drive on emphasis, and also in the mode of "creeping" speeds; then $\left(\omega \pm \omega_{c} \approx \omega\right)$, therefore

$$
\begin{aligned}
& A_{C L C 1}\left(\omega-\omega_{1}\right) \approx A_{C L C 2}\left(\omega+\omega_{1}\right) \approx A_{C L C}(\omega) ; \\
& \phi_{1}\left(\omega-\omega_{1}\right) \approx \phi_{2}\left(\omega+\omega_{1}\right) \approx \phi(\omega) .
\end{aligned}
$$

The modules of items $M_{1}\left(\omega-\omega_{1}\right)$ and $M_{2}\left(\omega+\omega_{1}\right)$ are equal, and in case of the frequency change, the amplitude and phase shift equally change (Fig. 1,a). 
The frequency responses of $C L C$ and $C L T$ in the relative units match, the expression for the torque takes a form:

$$
M=1,5 U_{i n} L_{m} I_{r} A_{C L C}(\omega) \cos \gamma \sin [\omega t-\phi(\omega)] .
$$

When $\omega_{1}$ and $\omega_{\mathrm{T}}$ are comparable in their values and $\left(\omega-\omega_{1}\right)$ and $\left(\omega+\omega_{1}\right)$ differ significantly, and because of influence of inertialess in the $C L C$ links, it is necessary to consider a limited bandwidth range of the frequencies of the $C L C$ items $\left(M_{1}\right.$ and $\left.M_{2}\right)$ changing differently as a frequency. Most considerably this difference is shown in the field of the cutoff frequency $\left(\omega_{c}\right)$; then in case of frequency rate of tension on the statorclose to the value of this frequency in case of $\omega_{1} \approx \omega_{c}$, the difference of frequencies $\left(\omega-\omega_{1}\right)$ lies within the working bandwidth range of CLC frequencies where the vector $\left(M_{1}\right)$ changes slightly. The other side frequency $\left(\omega+\omega_{1}\right)$ quits for the right boundary of the uniform passage of frequencies where range of a vector $\left(M_{2}\right)$ significantly decreases [11].

As a result, there is $\left|M_{1}\right|>\left|M_{2}\right|$. Therefore, the value and the direction of a resultant vector $\left(M=M_{1}+M_{2}\right)$ are defined largely by the vector of $M_{1}$ which changes a little (Fig. 1, b) [12]. At the resultant range of frequency characteristics, some broad banding of uniform passage of frequencies in case of the reduced values of the Bode plot of CLT is observed, and the phase of frequency characteristic CLT passes higher than the phase of the CLC frequency characteristics. The described phenomenon is shown stronger than frequency rates $\omega_{1}$ and the angular speed of the motor are closer to the frequency rate of a cutoff $\left(\omega_{c}\right)$ than $C L C$. In the range of very high frequencies of the $U_{i n}$ test signal of when $\omega \rightarrow \infty$, in case of any finite frequency rate $\left(\omega_{1}\right)$, the frequency responses of $C L C$ and $C L T$ match. Around mid frequencies, when values $\left(\omega_{1}\right.$ and $\left.\omega_{c}\right)$ are close, these characteristics differ, and for their computation, it is necessary to use the above-stated expression [13].

\section{Analysis results}

Calculation was executed for CLT in which the $C L T$ closed-loop of each phase of the stator was approximated by an oscillatory link of the second order with the transfer function

$$
W_{C L C}(p)=1 /\left(1+2 \zeta T_{p}+T^{2} p^{2}\right) .
$$

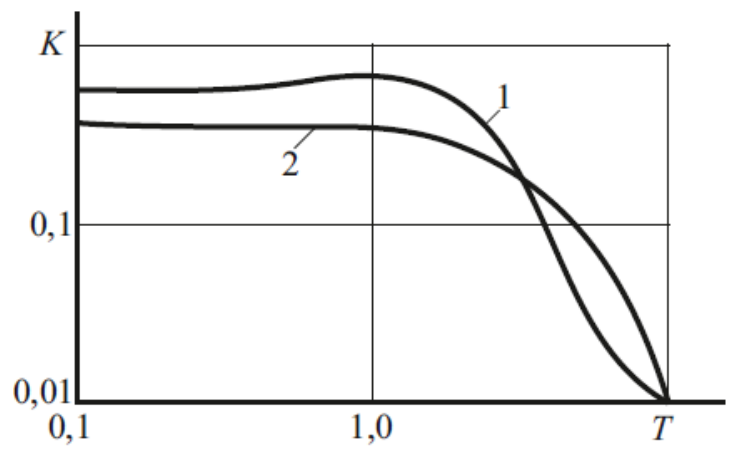

a)
Design bode plots corresponding to this transfer function are received by substituting of $p=\mathrm{j} \omega$ and for convenience are provided to functions of the dimensionless value $\left(\omega_{c}\right)$. The bode plot of the gain of $C L C$ and $C L T$ were provided in the relative units. Their values were taken for basic values of the current amplitude and the torque in case of $\omega_{1}=0$ and $\omega=0$ [14]. The coefficient of damping was accepted equal $\zeta=0,5$ that corresponds to a standard setup of the CLC closed loop with the relative cutoff frequency $\omega_{c}=1$ and the phase margin $\Delta \phi \approx 50^{\circ}$. The design bode plot of $C L C$ and $C L T$ in case of $\omega_{1}=0$ matches (Fig. 2, curves 1) and corresponds to the current transformation model of $i_{A}, i_{B}, i_{C}$ in the torque of $M$.

In case of the increased values $\omega_{1}$ when the angular speed of the electric drive approaches cutoff frequency $\left(\omega_{1} \approx \omega_{c}\right)$, the Bode plot of CLT changes (Fig. 2, curves 2). The gain decreases, but the Bode plot of the phase for about a decade around the frequency of the $C L C$ cutoff of passes on $40-50^{\circ}$ above that is explained by the dominating impact of the first item in the above-stated expression for the torque. On the Bode plot of CLT in comparison with the Bode plot of the phase of $C L C$ in case of values $\omega_{1}>\omega_{c}$, the increased rise of the phase not only remains, but also increases a little. However, the practical effect from this doesn't manage to be derived as receiving flat gain of $C L C$ on a section with the steep gradient of value of gain requires unfairly big voltage-forcing of power supplies of the stator circuit [15].

The described comparison of the Bode plot of CLC and CLT through all the range of frequencies shows the following. First, it is necessary to set a system of the electric drive at small speeds or even in case of the slowed-down motor as these modes are characterized by the smallest marginal stability. Secondly, at the stage of an approximate choice of structure and parameters of the correcting links in the electric drive it is possible to replace internal $C L T$ with $C L C$. This result seems very paradoxical but is full of decency: on the one hand, it simplifies calculation procedures, on the other - the inaccuracy of measurements only increases the "margin of safety" of calculations. At last, it is necessary to observe the principle of division of movements and to set

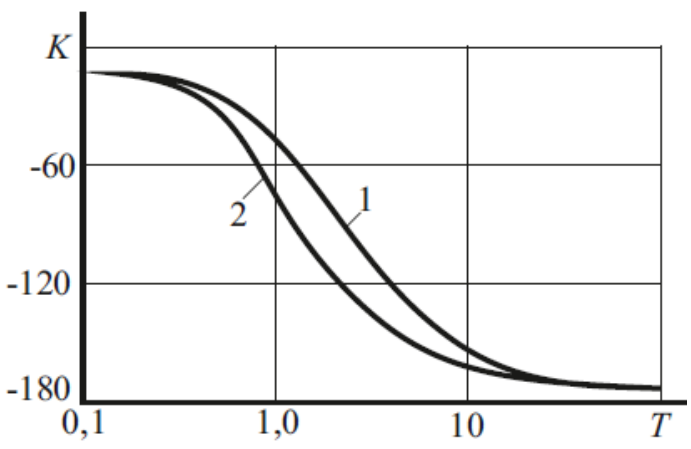

b)

Fig. 2. Bode plots of the gain (a) and phase (b) of the CLC and CLT: $\omega_{1}=0$ (curve 1) and $\omega_{1} \approx \omega_{c}$ (curve 2) 


\section{Электромеханические системы}

up $C L C$ of phase currents of the stator it is isolated from other actuating paths [16].

The experimental Bode plots were defined for specification of the accepted mathematical model of $C L C$, the accounting of all significant factors influencing the dynamic characteristics of the electric drive, the conclusion confirmation was obtained during calculations.

Bode plots were defined for $C L C$ of a phase and CLT of the electric drive. The block diagram of the experimental assembly and the characteristic are given in Fig. 3. For convenience of comparing of the options, the relative values of amplification gain in case of low frequencies are accepted as identical [17].

The trial sine signal of the different fixed frequencies in the range from 1 to $10000 \mathrm{rad} / \mathrm{s}$ was given from the output terminal of the measurement unit "Vector" [6] on an input of $P C G B$ and further arrived on three parallel operating $C L C$ of phase currents of the stator. Each $C L C$ was executed on the basis of the AI single-phase transistor autonomous inverters (Maxi Maestro 25/127 type). As the SM, the synchro- nous generator $B M Z 4,5$ was used $(4,5 \mathrm{kV} \cdot \mathrm{a} ; 1500 \mathrm{rpm}$; $\left.U_{p h}=127 \mathrm{~V} ; I_{p h}=10 \mathrm{~A}\right)$. The phase currents were measured by current sensors (CS) (Lem HY-05-P). In case of determination of the experimental characteristics of each of the local $C L C$ of the stator phase of the $S M$ for an output variable accepted voltage of one of $C S$, and the input voltage of the measurement unit "Vector" [18].

In case of the experimental determination of Bode plots CLT were used in series in the PLC programmable controller (Atmega 8535) which executed the computing operations corresponding to the $S M$ link, the rotor-position encoder of the RPE (Omron E6C3 AJ5C type) and the digital-analog converter $D A C$ (is an Atmega 8535 part). The value of assessment of the torque $M$ obtained on a $D A C$ output was accepted to an output signal of CLT [19].

The experimental Bode plots of $C L C$ and $C L T$ (Fig. 4) was removed in the diagram with a proportional regulator of the current, and in case of the amplification gain $\left(K_{C L C}=5\right)$ the open-loop circuit for-

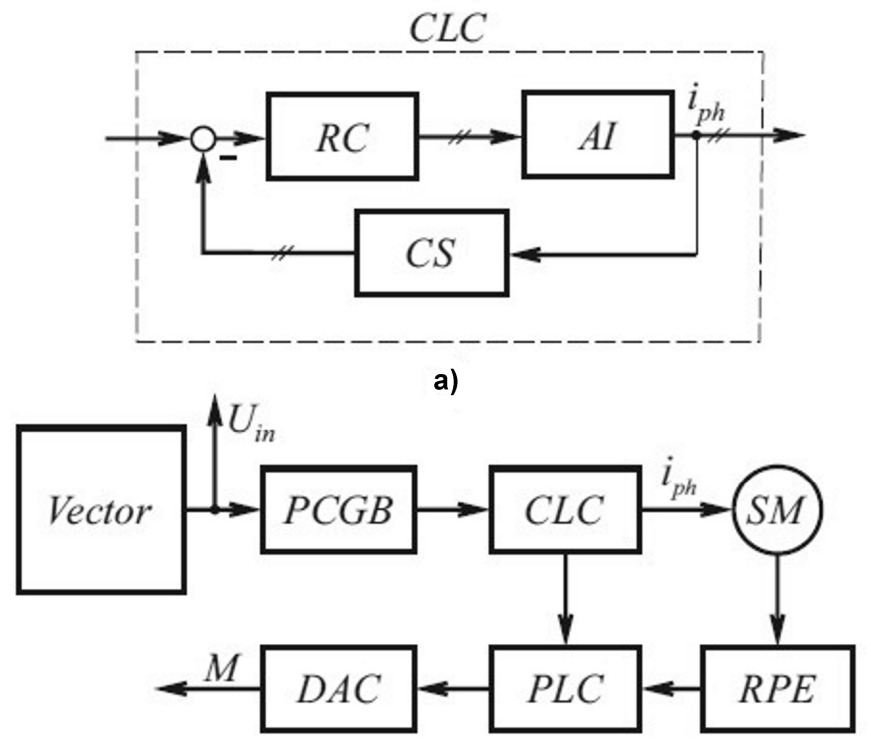

b)

Fig. 3. Block diagram for the experimental

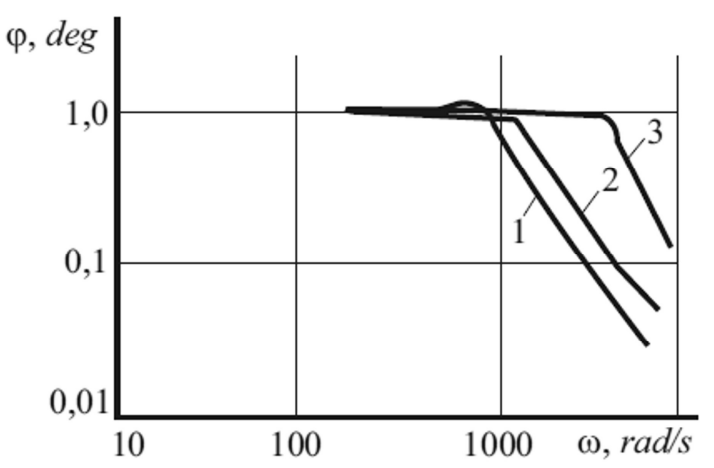

a)

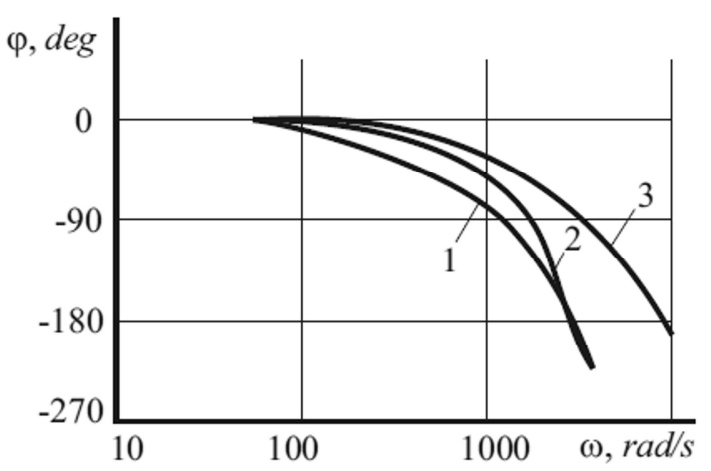

b)

Fig. 4. Experimental Bode plots: 1) $C L T$ of the $S M$; 2) $C L C$ of the $S M$; 3) $C L C$ of the filed regulated reluctance machine 
med by links of $R C, A I, C S$ (Fig. 3) has quite big (to $(2-4) \cdot 10^{-3} \mathrm{rad} / \mathrm{s}$ ) band of the uniform passage of frequencies. It allows almost complete weakening of the influence of cross coupling on the nature of the processes caused by existence of mutual induction between stator windings [20]. The experiment also showed the legitimacy of approximation of the CLC of a phase of the stator an oscillatory link of the second order in the range of frequencies at least to (2-4) $\cdot 10^{-3} \mathrm{rad} / \mathrm{s}$. A little smaller band of uniform passage of frequencies observed in CLT in comparison with $C L C$ should be explained with existence of some inertia in the procedure of the digital conversions, which are realized in a $P L C$ [21].

The experimental bode plots of $C L C$ of the stator phase (and, respectively, CLT) in the electric drive with the filed regulated reluctance machine [7] have a band of uniform passage of frequencies about 2-3 times wider (Fig. 4, curves 3). It can be explained by the fact that with increase in number of phases of the winding of the stator (the experiment was made in case of $m=6$ ) and an invariable bore diameter width of a phase zone, number of a phase winding and leakage inductance decreases [22].

\section{Conclusion}

In case of the frequency analysis of the dynamic properties of variable speed drive of an alternating current with the synchronous motors, it is convenient to consider CLT as the linear system with amplitude shift keying [2]. Using the principle of division of movements, it is possible to consider independent processes in the phase CLC and CLT. Application of the experimental characteristics allows, without complicating the mathematical description of system of the electric drive, to automatically consider influence of the cross couplings caused by existence of reciprocal magnetic coupling between windings in the motor. The modern inverters executed on threephase converters allow receiving in phase circuits of regulation of current a band of uniform passage of several thousand a radian in a second. The rough estimate of the dynamic properties of the torque control loop of the can be received using only bode plots of control loop of the phase currents of the stator.

The work was supported by Act 211 Government of the Russian Federation, contract № 02.A03.21.0011.

\section{References}

1. Efimenko E.I. Physical Processes in Salient Poles Alternating Current Machines and their Analytical Description Taking into Account Discrete Windings. Electrical Technology Russia, 2001, iss. 4, pp. 27-36.

2. Golubev A.N., Lapin A.A. A Multiphase Synchronous Electric Drive. Electrical Technology Russia, 2005, iss. 2, pp. 43-47.

3. Usynin Yu.S., Grigor'ev M.A., Vinogradov K.M.
[Electric Drives and Generators with Synchronous Reactive Machine of Independent Excitation]. Electrical Technology Russia, 2007, iss. 3, pp. 21-27. (in Russ.)

4. Ivanov E.S. [Principles of Using Phase EMF in Electric Drives with Frequency-Current Control of AC Motor Torque]. Electrical Technology Russia, 2008, iss. 7, pp. 32-42. (in Russ.)

5. Shreyner R.T., Krivovyaz V.K., Kalygin A.I. [Control of Direct Frequency Converters with PWM in AC Drive Systems]. Electrical Technology Russia, 2007, iss. 5, pp. 26-38. (in Russ.)

6. Dement'ev Yu.N. [Mathematical Description of Static and Dynamic Modes of an Electric Drive of an Alternating Current with Gate Converters]. Electrical Technology Russia, 2009, iss. 12, pp. 45-51. (in Russ.)

7. Usynin Yu.S., Grigor'ev M.A., Shishkov A.N. [Frequency Characteristics of Torque Control Channel in Synchronous Electric Drives]. Electrical Technology Russia, 2012, iss. 4, pp. 54-60. (in Russ.)

8. Karzhavov B.N. [About Control of Torque of Executive Motor in Electric Drives]. Electrical Technology Russia, 2011, iss. 2, pp. 39-46. (in Russ.)

9. Dement'ev Yu.N. [Mathematical Description of AC Drives with a Gate Converter]. Electrical Technology Russia, 2012, iss. 6, pp. 36-42. (in Russ.)

10. Terekhov V.M. [Modern Control Methods and their Use in the Electric Drive]. Russian Electrical Engineering, 2000, iss. 2, pp. 25-28. (in Russ.)

11. Vayner G.A., Stroganov B.G. Controllable Synchronous Motor in System with Frequency and Phase Feedback. Russian Electrical Engineering, 2005 , iss. 6, pp. 1-9.

12. Litvinov B.V., Davydenko O.B. Synchronous Reluctance Motor with a Laminated Rotor. Russian Electrical Engineering, 2009, vol. 80, iss. 1, pp. 29-32.

13. Litvinov B.V., Davydenko O.B. Synchronous Reluctance Motors with Lowered Magnetic Conductivity along Transverse Axis. Russian Electrical Engineering, 2010, vol. 81, iss. 3, pp. 121-125. DOI: 10.3103/S106837121003003X

14. Solomatin A.A., Meshcheryakov V.N., Levin P.N. [Synchronized Asynchronous Electric Drive with Frequency Control]. Elektromekhanika [Russian Electromechanics], 2009, iss. 2, pp. 51-57. (in Russ.)

15. Davydenko O.B., Kazanskiy V.M. Substitution Circuit of Reactive Synchronous Motor with Laminated Rotor. Russian Electrical Engineering, 1998, iss. 2, pp. 18-22.

16. Kobzev A.A., Novikova N.A., MishulinYu.E. Electric Drive Control System with Control Signal Modulation. Electrical Technology Russia, 1997, iss. 4, pp. 21-25.

17. Plakhtyna E.G., Shakaryan Yu.G., Vinitskiy Yu.D., Vasyliv K.N., Lozinskiy A.S. Mathematical Model of AC Adjustable-Frequency Electric Drive. Electrical Technology Russia, 1996, iss. 3, pp. 53-59. 
18. Kurbasov A.S. Parameters of Reluctance Motors. Electrical Technology Russia, 1994, iss. 12, pp. 58-62.

19. Tarasov V.N. [Low-Power Synchronous Electric Drives with Adjustable Magnetic Excitation]. Electrical Technology Russia, 1990, iss. 11, pp. 38-43. (in Russ.)

20. Kodkin V.L., Gafiyatullin R.Kh., Khaybzhov E.R. [Frequency Analysis of Digital Control Systems for High-Precision Servomechanical Drives with Regard to the Suppression Link]. Bulletin of South Ural State University, Series "Power Engineering”, 2002, iss. 2, pp. 60-63. (in Russ.)
21. Usynin Yu.S., Butakov S.M., Grigor'ev M.A., Karavaev G.V., Vinogradov K.M. [Experimental Frequency of Characteristics of AC Drives with Valve Frequency Converters]. Bulletin of South Ural State University, Ser. Power Engineering, 2002, iss. 2, pp. 67-70. (in Russ.)

22. UsyninYu.S., Monyushko N.D., Grigor'ev M.A., Karavaev G.V., Vinogradov K.M. [Electric Drive With Synchronous Independent-excitation Jet Engine]. Bulletin of South Ural State University, Ser. Power Engineering, 2001, iss. 1, pp. 70-77. (in Russ.)

Received 5 April 2017

удк 62-83:621.313.3

DOI: 10.14529/power170210

\title{
ОСОБЕННОСТИ ЧАСТОТНОГО АНАЛИЗА КОНТУРА РЕГУЛИРОВАНИЯ МОМЕНТА В ЭЛЕКТРОПРИВОДЕ ПЕРЕМЕННОГО ТОКА
}

\author{
А.Н. Шишков, Д.А. Сычев, Н.В. Савостеенко, \\ М.Н. Крупнова, А.А. Землянский \\ Южно-Уральский государственный университет, г. Челябинск
}

\begin{abstract}
В работе приведена и математически описана структурная схема канала регулирования момента синхронного двигателя. Рассматривается прохождение синусоидального сигнала в контуре регулирования момента, приведены уравнения для описания динамических свойств контура регулирования тока. Рассмотрены особенности частотных характеристик канала регулирования электромагнитного момента в частотно-регулируемых электроприводах с синхронными электрическими машинами. Канал регулирования момента рассматривается как линейная система с амплитудной модуляцией. Проведен сравнительный анализ экспериментальных и расчетных логарифмических частотных характеристик контуров регулирования тока и момента.

Ключевые слова: электропривод, частотное регулирование, логарифмические частотные характеристики, синхронный реактивный двигатель.
\end{abstract}

\section{Лumepamypa}

1. Ефименко, Е.И. Физические прочессы в явнополюсных машинах переменного тока и их аналитическое описание с учетом дискретности обмоток / Е.И. Ефименко // Электричество. - 2001. - № 4. - C. $27-31$.

2. Голубев, А.Н. Многофазный синхронный электропривод / А.Н. Голубев, А.А. Лапин // Электричество. -2005 . - № 2. - C. 43-48.

3. Усынин, Ю.С. Электроприводы и генераторы с синхронной реактивной машиной независимого возбуждения / Ю.С. Усынин, М.А. Григорьев, К.М. Виноградов // Электричество. - 2007. - № 3. - С. $21-27$.

4. Иванов, Е.С., Принщипь использования фазных ЭДС в электроприводах с частотно-токовым управлением моментом двигателей переменного тока / Е.С. Иванов // Электричество. - 2008. - № 7. - C. 32-42.

5. Шрейнер, Р.Т. Управление непосредственными преобразователями частоты с ШИМ в системах приводов переменного тока / Р.Т. Шрейнер, В.К. Кривовяз, А.И. Кальгин // Электричество. - 2007. - № 5. C. $26-38$.

6. Дементьев, Ю.Н. Математическое описание статических и динамических режимов электропривода переменного тока с вентильными преобразователями / Ю.Н. Дементьев // Электричество. - 2009. № 12. - C. 45-51.

7. Каржавов, Б.Н. Об управлении моментом исполнительного двигателя в электроприводах / Б.Н. Каржавов // Электричество. - 2011. - № 2. - С. 39-46.

8. Усынин, Ю.С. Об управлении моментом исполнительного двигателя в электроприводах / Ю.С. Усынин, М.А. Григорьев, А.Н. Шииков // Электричество. - 2012. - № 4. - С. 54-60. 
9. Дементьев, Ю.Н. Математическое описание приводов переменного тока с вентильным преобразователем / Ю.Н. Дементьев // Электричество. - 2012. - № 6. - С. 36-42.

10. Терехов, В.М. Современные способы управления и их применение в электроприводе / В.М. Терехов // Электротехника. - 2000. - №2. - C. 25-28.

11. Вайнер, Г.А. Регулируемьй синхронный двигатель в системе с частотной и фазовой обратными связями / Г.А. Вайнер, Б.Г. Строганов // Электротехника. - 2005. - № 6. - С. 3-10.

12. Литвинов, Б.В. Синхронный реактивный электродвигатель со слоистым ротором / Б.В. Литвинов, О.Б. Давыденко // Электротехника. - 2009. - № 1. - С. 33-38.

13. Литвинов, Б.В., Синхронные реактивные электродвигатели с пониженной магнитной проводимостью по поперечной оси / Б.В. Литвинов, О.Б. Давыденко // Электротехника. - 2010. - № 3. - С. 15-20. DOI: $10.3103 / S 106837121003003 X$

14. Соломатин, А.А. Синхронизированный асинхронный электропривод с частотным управлением / А.А. Соломатин, В.Н. Мещеряков, П.Н. Левин // Электромеханика. - 2009. - № 2. - С. 51-57.

15. Давыденко, О.Б. Схема замещения синхронного реактивного электродвигателя со слоистым ротором / О.Б. Давыденко, В.М. Казанский // Электротехника. - 1998. - № 2. - C. 18-23.

16. Кобзев, А.А. Система управления электроприводом с модулящией управляющего сигнала / А.А. Кобзев, Н.А. Новикова, Ю.Е. Мишулин // Электричество. - 1997. - № 4. - С. 21-26.

17. Система управления электроприводом с модулящией управляющего сигнала / Е.Г. Плахтына, Ю.Г. Шакарян, Ю.Д. Виниикий и др. // Электричество. - 1996. - № 3. - С. 53-60.

18. Курбасов, А.С. Параметры синхронных реактивных электродвигателей / А.С. Курбасов // Электричество. - 1994. - № 12. - С. 58-63.

19. Тарасов, В.Н. Маломощчный синхронный электропривод с регулируемым магнитным возбуждением / В.Н. Тарасов // Электротехника. - 1990. - № 11. - С. 38-43.

20. Кодкин, В.Л. Частотный анализ циифровых систем управления высокоточными следямими электроприводами с учетом звена подавления / В.Л. Кодкин, Р.Х. Гафиятуллин, Э.Р. Хайбжов // Вестник ЮУрГУ. - 2002. - № 2. - С. 60-63.

21. Экспериментальные частотные характеристики электроприводов переменного тока с вентильными преобразователями частоты / Ю.С. Усынин, С.М. Бутаков, М.А. Григорьев и др. // Вестник ЮУрГУ. 2002. - № 2. - C. 67-70.

22. Электропривод с синхронным реактивным двигателем независимого возбуждения / Ю.С. Усынин, Н.Д. Монюшко, М.А. Григорьев и др. // Вестник ЮУрГУ. - 2001. - № 1. - С. 70-77.

Шишков Александр Николаевич, канд. техн. наук, доцент, зав. кафедрой «Автоматизированный электропривод», Южно-Уральский государственный университет, г. Челябинск; shan1982@mail.ru.

Сычев Дмитрий Александрович, старший преподаватель, кафедра «Автоматизированный электропривод», Южно-Уральский государственный университет, г. Челябинск; dmitry.epa@gmail.com.

Савостеенко Никита Вадимович, магистрант, кафедра «Автоматизированный электропривод», ЮжноУральский государственный университет, г. Челябинск; nikita.epa@gmail.com.

Крупнова Мария Николаевна, студентка, кафедра «Автоматизированный электропривод», ЮжноУральский государственный университет, г. Челябинск; masha.krupnova.epa@gmail.com.

Землянский Андрей Алексеевич, студент, кафедра «Автоматизированный электропривод», ЮжноУральский государственный университет, г. Челябинск; andrey.zemlyansky@gmail.com.

Поступила в редакцию 5 апреля 2017 z.

\section{ОБРАЗЕЦ ЦИТИРОВАНИЯ}

Features of Frequency Analysis of Torque Control Loop in AC Electric Drives / A.N. Shishkov, D.A. Sychev, N.V. Savosteenko et al. // Вестник ЮУрГУ. Серия «Энергетика». - 2017. - Т. 17, № 2. - С. 75-81. DOI: $10.14529 /$ power 170210

\section{FOR CITATION}

Shishkov A.N., Sychev D.A., Savosteenko N.V., Krupnova M.N., Zemlyansky A.A. Features of Frequency Analysis of Torque Control Loop in AC Electric Drives. Bulletin of the South Ural State University. Ser. Power Engineering, 2017, vol. 17, no. 2, pp. 75-81. DOI: $10.14529 /$ power 170210 